Niepełnosprawność. Dyskursy pedagogiki specjalnej

Nr 27/2017

Disability. Discourses of special education

No. $27 / 2017$

Edyta Nieduziak

Uniwersytet Śląski w Katowicach

\title{
Miejsce pedagogiki specjalnej w kształceniu nauczycieli: oczekiwania, możliwości, opinie - kontekst wymagań prawych i rzeczywistości szkolnej
}

Artykuł dotyczy przygotowania nauczycieli szkół ogólnodostępnych do edukacji włączającej. Prezentuje uwarunkowania prawne i konfrontuje je z badaniem wśród nauczycieli - słuchaczy studiów podyplomowych na kierunkach z zakresu pedagogiki specjalnej, oraz wśród studentów kierunków niepedagogicznych, przygotowujących się do pracy jako nauczyciele. Celem badań było poznanie: deklarowanych motywacji do podjęcia kształcenia podyplomowego i nauczycielskiego, opinii na temat kształcenia z zakresu pedagogiki specjalnej, preferowanych form kształcenia uczniów niepełnosprawnych. Autorka wykorzystała sondaż diagnostyczny, technikę ankiety. Wyniki wskazują, że nastawienie wobec form kształcenia uczniów niepełnosprawnych może mieć związek nie tylko z przygotowaniem nauczycieli, ale i z ich motywacją do pracy z niepełnosprawnymi. Nauczyciele preferują dotychczasowe, segregacyjne formy kształcenia uczniów niepełnosprawnych. Studenci mają odwagę pracy w systemie edukacji niesegregacyjnej. Nie znają jeszcze realiów pracy jako nauczyciele, ale mają pozytywne doświadczenia bycia uczniami klas integracyjnych. Studenci chętniej kształcą się w pedagogice specjalnej. Nauczyciele nie są chętni do zmian, jakich wymagają niepełnosprawni uczniowie ale motywuje ich obawia przed utratą pracy.

Słowa kluczowe: edukacja włączająca, nauczyciel, uczniowie z niepełnosprawnością, nauczyciele edukacji włączającej, pedagogika specjalna

\section{Place of special education in teachers' training: expectations, opportunities, opinions - the context of legislation acts and school reality}

The paper presents study of preparing teachers of generally available schools for the inclusive education. It presents legal conditions and compares them with researches amongst teachers the post-graduate education's students of the special education and amongst students of nonpedagogic faculty, preparing to the work as teachers. The purpose of research was to know: declared motivations for entertaining the postgraduate study or the teaching education, the opinion on the study of the special education, preferred form of education for students with disabilities. The author used the diagnostic survey, technique of the questionnaire form. Results show that the attitude towards forms of education of pupils with disability can correlate not only with preparing teachers, but also with their motivation to the work with disabled persons. Teachers prefer current, segregation forms of education of pupils with disability. Students have a courage of the 
work in nonsegregation educational system. They don't still know the reality of the work as teachers but they have positive experiences of being pupils of integration classes. Students more willingly study in the special needs education. Teachers aren't willing for changes disabled pupils require which, but they are motivated by anxiety of loss of the work.

Key words: inclusive education, teachers, pupils with disabilities, teachers of inclusive education, special education

\section{Wprowadzenie - wokół pojęcia edukacji włączającej}

Andreas Hinz [1999] określił edukację włączającą mianem „kopernikańskiego przewrotu", sugerując, że rzeczywiste wcielenie jej do praktyki szkolnej nie odbędzie się na drodze zmian ewolucyjnych, lecz wymaga przyjęcia zupełnie nowej wizji „,demokratycznej szkoły publicznej w pluralistycznym społeczeństwie późnej nowoczesności" [Szumski 2010, s. 38]. Nie jest zatem rzeczą prostą urzeczywistnienie idei, która wymaga radykalnych zmian we wszystkich elementach procesu kształcenia, a ponadto sama w sobie nie jest też ściśle określona. Już sama analiza pojęcia edukacji włączającej uwidacznia jej niejednoznaczność [Chrzanowska 2015, s. 554-563; Szumski 2010, s. 11-27], co przekłada się na praktykę szkolną i różnorodne modele kształcenia uczniów niepełnosprawnych [por. Cylkowska-Nowak 2000; Szumski 2009]. Przyjmując jednak za Małgorzatą Kupisiewicz [2014, s. 97], że „edukacja włączająca zakłada (...) takie przekonstruowanie systemu szkolnego, by stworzyć wszystkim uczniom, niezależnie od rodzaju czy głębokości niepełnosprawności, nie tylko możliwość integracji przestrzennej i programowej $\mathrm{w}$ procesie edukacji, ale także zadbać o ich potrzeby osobiste i społeczne, zapewniając im warunki do rozwinięcia poczucia przynależności do społeczności uczniów szkoły ogólnodostępnej, znajdującej się najbliżej miejsca zamieszkania, szanse integracji w środowisku lokalnym", wprowadzenie jej w życie wymaga fundamentalnych zmian w procesach: dydaktycznym i wychowawczym, a co za tym idzie - przygotowania całej rzeszy osób, które potrafiłyby realizować hasło „Edukacja dla Wszystkich” i dla każdego [Deklaracja z Salamanki]. Chęć dokonania owego „kopernikańskiego przewrotu” czy, inaczej rzecz ujmując, dokonania swoistej rewolucji w kształceniu osób niepełnosprawnych, polegającej na odejściu od kształcenia specjalnego jako jedynego miejsca ich edukacji, nie powiedzie się bez przygotowania profesjonalnej kadry, która posiada zarówno umiejętności i kompetencje praktyczne, ale nade wszystko rozumie przesłanki przemawiające za dokonywanymi zmianami. Zatem, niezbędni są wykonawcy szczytnej idei - nauczyciele. „Odpowiednie przygotowanie całej kadry nauczycielskiej jest kluczowym czynnikiem w promowaniu rozwoju szkół integracyjnych" - czytamy w Wytycznych dla dziatan w zakresie specjalnych potrzeb edukacyjnych 
[tamże, C 40] uzupełniających bazowy dla edukacji włączającej dokument Deklarację z Salamanki.

\section{Kontekst wymagań prawnych}

Konsekwencją ratyfikowania przez Polskę powyższego dokumentu, jak również wcześniejszych przemian ustrojowych, a wraz z nimi sposobów myślenia o edukacji, było dokonywanie zmian, m.in. Ustawy o systemie oświaty albo wprowadzanie przepisów - licznych rozporządzeń regulujących kształcenie uczniów o specjalnych potrzebach edukacyjnych [Sadowska 2016, por. Gajdzica, Iwińska 2013]. Aczkolwiek, jak zauważa Iwona Chrzanowska [2015, s. 535], sytuacja edukacyjna uczniów z niepełnosprawnością zaczęła się zmieniać dopiero wraz z reformą systemu oświaty w 1991 roku, wprowadzeniem kształcenia integracyjnego w 1993 roku, i prawem do kształcenia w szkole ogólnodostępnej od 1999 roku. Niemal dwudziestoletnie doświadczenia w przeobrażaniu polskiej oświaty w kierunku tzw. "systemu otwartego" również dla uczniów z niepełnosprawnością, znajdują swoje odbicie także w przepisach dotyczących nabywania kwalifikacji pedagogicznych [Dz. U. z 2012 r., poz. 131], niezbędnych do wykonywania zawodu nauczyciela, jak też kwalifikacji, jakie powinni posiadać nauczyciele, niebędący pedagogami specjalnymi, a prowadzący czy też chcący prowadzić zajęcia z uczniami niepełnosprawnymi [Dz. U z dnia 31 sierpnia 2015 r., poz. 1264] ${ }^{1}$. Ponadto dwa Rozporządzenia Ministra Edukacji Narodowej:

- z dnia 24 lipca 2015 r. w sprawie warunków organizowania kształcenia, wychowania i opieki dla dzieci i młodzieży niepełnosprawnych, niedostosowanych społecznie i zagrożonych niedostosowaniem społecznym (Dz. U. z 2015 r., poz. 1113), oraz

- z dnia 30 kwietnia $2013 \mathrm{r}$. w sprawie zasad udzielania i organizacji pomocy psychologiczno-pedagogicznej w publicznych przedszkolach, szkołach i placówkach (Dz. U. z 2013 r., poz. 532),

poza tym, że regulują możliwość uczęszczania do szkół ogólnodostępnych uczniów niepełnosprawnych oraz wymagają od szkół organizowania pomocy psychologiczno-pedagogicznej, wskazują na ważną rolę specjalistów, a zatem osób posiadających wiedzę i umiejętności również z zakresu pedagogiki specjalnej, w pracy z uczniami ze specjalnymi potrzebami edukacyjnymi. Słowem, nie można przygotować kompetentnej kadry nauczycieli, gotowej do pracy w warunkach eduka-

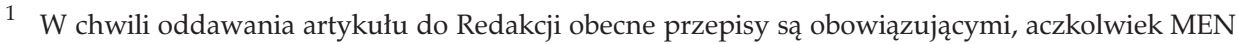
opublikował projekt nowego Rozporządzenia w sprawie szczegółowych kwalifikacji wymaganych od nauczycieli, które miałoby obowiązywać od 1 września 2017 r. http://www.prawo.vulcan. edu.pl/pages/adds/projekty/170208_kwalifikacje_nauczycieli.pdf [dostęp 31.05.2017]. 
cji włączającej, bez kształcenia w zakresie pedagogiki specjalnej. Tym bardziej, że - jak czytamy w publikacjach Ośrodka Rozwoju Edukacji - „W 2012 r. Polska ratyfikowała Konwencję ONZ o prawach osób niepełnosprawnych i tym samym zadeklarowała, że celem polityki oświatowej państwa jest wprowadzenie włączającego modelu kształcenia. Wymaga to m.in. zmian w szkolnictwie ogólnodostępnym (...). W systemie oświaty oznacza to odejście od modelu segregacyjnego, w którym bardzo duży odsetek dzieci niepełnosprawnych (nie tylko tych z najcięższymi dysfunkcjami) uczy się w szkołach specjalnych. Promowana powinna być edukacja włączająca, prowadzona w klasach ogólnodostępnych, $\mathrm{w}$ szkołach rejonowych, najbliższych środowisku życia ucznia. Wymaga to przygotowania szkół do przyjęcia dzieci niepełnosprawnych, w tym zapewnienia specjalistycznego, merytorycznego wsparcia dla nauczycieli i dyrektorów szkól" [Dziecko z niepetnosprawnościq..., s. 9]. W tej samej publikacji przeczytamy dalej, że edukacja włączająca nie powinna być rozumiana jako forma zastępująca kształcenie w szkołach specjalnych, „,nie jest atakiem na szkoły specjalne" [tamże, s. 11], jednakże realia polskich szkół rzeczywiście wskazują na nacisk w realizacji edukacji włączającej, choć nie zawsze z oczekiwanymi dobrymi rezultatami [por. Dudzińska, Roszewska 2016; Gajdzica 2011]. W tym miejscu należy choćby wspomnieć publikacje Grażyny Dryżałowskiej [2004] czy Anny Zamkowskiej [2011], wskazujące na, wciąż ważną a nawet niezbędną, obecność szkół specjalnych w kształceniu uczniów z niepełnosprawnością. Nie zmienia to jednak faktu, że od 2004 roku w Polsce widoczna jest tendencja spadkowa udziału uczniów ze specjalnymi potrzebami edukacyjnymi w szkolnictwie segregacyjnym [tamże] na rzecz upowszechniania edukacji włączającej. Zatem zarówno kontekst prawny, jak i wynikająca z niego rzeczywistość szkolna, potwierdzają coraz większą popularność kształcenia integracyjnego i włączającego.

\section{Przygotowanie nauczycieli do pracy z uczniami niepełnosprawnymi - rzeczywistość szkolna}

Zarysowany powyżej stan rzeczy wskazuje, że jednym z poważnych wyzwań jakie stają przed współczesnymi nauczycielami, jest nabywanie wiedzy z zakresu pedagogiki specjalnej. Jest o tym mowa także w Wytycznych... w odniesieniu zarówno do działań przygotowujących przyszłych nauczycieli, jak i szkoleń dla już pracujących. „Programy szkoleniowe przed zatrudnieniem powinny być zapewnione wszystkim przygotowującym się do zawodu nauczyciela, tak szkoły podstawowej, jak i średniej, z przesłaniem pozytywnej postawy wobec niepełnosprawności, ucząc tym samym co można osiągnąć w szkołach przy wykorzystaniu lokal- 
nie dostępnych służb pomocniczych" [Wytyczne..., C 41]. Ten warunek, został zrealizowany $\mathrm{w}$ Polsce na poziomie aktu prawnego dopiero w 2012 roku rozporządzeniem MNiSW w sprawie standardów kształcenia przygotowującego do wykonywania zawodu nauczyciela [Dz. U. z 2012 r., poz. 131], w którym w opisie efektów kształcenia znajdziemy m.in. wymóg posiadania wiedzy na temat specyfiki funkcjonowania uczniów ze specjalnymi potrzebami edukacyjnymi, w tym uczniów szczególnie uzdolnionych [efekt 1i] oraz umiejętności projektowania i prowadzenia badań diagnostycznych w praktyce pedagogicznej (...) uwzględniającą specjalne potrzeby edukacyjne uczniów z zaburzeniami w rozwoju [efekt 1f].

Ponadto, rozporządzenie to przewiduje możliwość zdobywania kwalifikacji $\mathrm{w}$ zakresie pedagogiki specjalnej na studiach podyplomowych $\mathrm{w}$ ramach realizacji modułu 5. Z drugiej strony inne akty prawne, zwłaszcza rozporządzenie w sprawie warunków organizowania kształcenia, wychowania i opieki dla dzieci i młodzieży niepełnosprawnych, niedostosowanych społecznie i zagrożonych niedostosowaniem społecznym nakłada obowiązek zatrudnienia w szkole, w której są tacy uczniowie nauczycieli posiadających kwalifikacje w zakresie pedagogiki specjalnej, w celu współorganizowania kształcenia uczniów niepełnosprawnych lub specjalistów, lub w przypadku klas I-III szkoły podstawowej-asystenta nauczyciela bądź pomoc nauczyciela [\$7. 2; 7.3]. Tym samym zarówno przyszli nauczyciele, jak i ci aktywni zawodowo, zostali zobligowani do poszerzania swojej wiedzy i zdobywania nowych kwalifikacji. Jednakże w przypadku osób zdobywających kwalifikacje pedagogiczne do nauczania wybranego przedmiotu - ich przygotowanie z zakresu pedagogiki specjalnej czy też szerzej w pracy z uczniami o specjalnych potrzebach edukacyjnych - może mieć charakter elementarny, zwłaszcza, że tego typu przygotowanie odbywa się często w ramach studiów I albo II stopnia na specjalności nauczycielskiej albo $\mathrm{w}$ ramach zdobywania dodatkowych uprawnień podczas studiów. Oczywiście możliwe jest także zdobywanie tych kwalifikacji na drodze kształcenia podyplomowego.

Tymczasem nauczyciele przygotowujący się do pracy z uczniami niepełnosprawnymi, np. w ramach zajęć specjalistycznych, podejmują kształcenie na studiach podyplomowych. Często te dwie grupy różni nie tylko wiek, ale także zasób doświadczeń życiowych i zawodowych. Nieco rzecz upraszczając można jednak powiedzieć, że reprezentują one różne pokolenia. Osobami przygotowującymi się do nauczania przedmiotu są zazwyczaj studenci, którzy, choć nie mają doświadczenia w pracy nauczyciela, to jednak ciągle pamiętają szkołę z perspektywy ucznia. Część z nich ma już doświadczenie uczenia się w klasie integracyjnej. Natomiast czynni zawodowo nauczyciele to w większości osoby, które przechodziły przygotowanie do tego zawodu bez treści z zakresu pedagogiki specjalnej. Część z nich, podejmując decyzję o wyborze zawodu nauczyciela, nie wyobrażała sobie, że do szkoły ogólnodostępnej mogą uczęszczać uczniowie niepełnosprawni. 
W czasach gdy przechodzili własne przygotowanie pedagogiczne, tacy uczniowie trafiali do systemu segregacyjnego.

\section{Opis i charakterystyka badań własnych}

Mając na uwadze te odmienności podjęto badania w dwóch grupach: grupie studentów przygotowujących się do pracy w zawodzie nauczyciela (w ramach specjalizacji nauczycielskiej albo tzw. kształcenia modułowego, czyli dodatkowych zajęć, których ukończenie daje kwalifikacje pedagogiczne) oraz w grupie nauczycieli, którzy podjęli kształcenie na studiach podyplomowych z zakresu autyzmu albo edukacji i rehabilitacji osób z niepełnosprawnością intelektualną. Celem badań było poznanie deklarowanych motywacji do podjęcia kształcenia $\mathrm{w}$ odpowiednich formach, oraz opinii na temat kształcenia z zakresu pedagogiki specjalnej. Interesowało nas również, jaka jest wśród badanych preferencja co do wyboru formy kształcenia najbardziej odpowiedniej dla osób niepełnosprawnych, z perspektywy własnych doświadczeń prywatnych albo zawodowych. Chodziło o uzyskanie odpowiedzi na następujące pytania:

- co motywuje badanych studentów do zdobywania kwalifikacji do wykonywania zawodu nauczyciela?

- co motywuje badanych nauczycieli do zdobywania kwalifikacji w zakresie pedagogiki specjalnej?

- jaki jest stosunek osób badanych do treści kształcenia z zakresu pedagogiki specjalnej?

- jakie są preferowane przez badanych formy kształcenia specjalnego (szkoła specjalna, szkoły/oddziały integracyjne, edukacja w szkołach ogólnodostępnych)? Badaniom poddani zostali:

- studenci Uniwersytetu Wrocławskiego studiów I i II stopnia kierunków niepedagogicznych, zdobywający kwalifikacje pedagogiczne do nauczania przedmiotu (73 osoby, w tym 36 studentów kierunków ścisłych i 37 studentów kierunków humanistycznych);

- słuchacze studiów podyplomowych z zakresu pedagogiki specjalnej (edukacja i rehabilitacja osób z niepełnosprawnością intelektualną (29 osób), edukacja i rehabilitacja osób z autyzmem w tym z zespołem Aspergera (29 osób) z Uniwersytetu Jana Kochanowskiego oraz Państwowej Wyższej Szkoły Zawodowej w Tarnobrzegu.

Dobór grup był celowy. Średnia wieku w grupie studentów wynosiła 21 lat i 6 miesięcy, kobiety stanowiły 80,2\% a mężczyźni - 19,2\%. Natomiast w grupie nauczycieli średnia wieku wynosiła 38 lat i 8 miesięcy, kobiety stanowiły $94,2 \%$, mężczyźni - 5,8\%. 
W badaniach wykorzystano metodę sondażu diagnostycznego, technikę ankiety i autorski kwestionariusz ankiety, zawierający pytania otwarte oraz jedno pytanie zamknięte dotyczące wyboru formy kształcenia uczniów niepełnosprawnych. Badani wypełniali kwestionariusze po zakończeniu przedmiotu „Pedagogika - uczeń ze specjalnymi potrzebami edukacyjnymi" - odnosi się do studentów zdobywających uprawnienia pedagogiczne, i na zakończenie cyklu kształcenia dotyczy czynnych zawodowo nauczycieli kształcących się na studiach podyplomowych. Analizie zostało poddanych 131 ankiet. Badania zostały przeprowadzone w kwietniu i maju 2017 roku.

\section{Analiza wyników badań własnych}

Wśród odpowiedzi na pytania dotyczące motywacji do podjęcia kształcenia, przygotowującego do wykonywania zawodu nauczyciela zauważyć można dwie wyraźne tendencje dzielące studentów kierunków humanistycznych od studentów kierunków ścisłych. Ci pierwsi, zwłaszcza studenci kierunków filologicznych, kierowali się $\mathrm{w}$ wyborze specjalności nauczycielskiej zainteresowaniem, wcześniejszymi pozytywnymi doświadczeniami szkolnymi, wzorami nauczycieli, których chcieli naśladować. Znamienna w tym względzie jest wypowiedź jednej ze studentek:

Zdecydowałam się na to, ponieważ poczułam swego rodzaju powołanie. W liceum miałam przyjemność obserwować pracę paru świetnych nauczycieli i pomyślałam: „Rany! Chcę być taka jak oni!" Ponadto, bardzo interesuję się psychologiq, ogólnie człowiekiem - jego złożonościa, skomplikowanymi emocjami. Chciałabym zostać nauczycielem także po to, aby coś zmienić.

Niespełna $20 \%$ ankietowanych tej grupy, traktuje swój przyszły zawód jako misję, pasję i spełnienie marzeń. Około $1 / 4$ wyobraża sobie swoją przyszłą pracę jako po prostu przekazywanie wiedzy, zaś dla ok. 18\% zawód nauczyciela wiąże się z ciekawą profesją. W tym idealistycznym obrazie wyróżnia się kilka wypowiedzi, zwłaszcza studentów historii, którzy wybrali specjalność nauczycielską $\mathrm{w}$ drodze eliminacji innych nieciekawych specjalności. Obraz dopełniają wypowiedzi, z których wynika, że studenci zdecydowali się na zdobycie kwalifikacji nauczycielskich, jako dodatkowych, zwiększających ich szanse na rynku pracy, albo jako możliwość zrealizowania zainteresowań, gdy mają poczucie zabezpieczenia w postaci ukończonego innego kierunku studiów.

Rozpoczynając studia myślałem o pracy w przyszłości jako nauczyciel. Większość znajomych odradzała mi specjalizację nauczycielska ze względu na maty rynek pracy; dlatego też wybrałem inna. Filologia polska to mój drugi kierunek - bez wahania wybrałem specjalizację nauczycielską. Moim marzeniem jest praca w szkole średniej. 
Zupełnie inaczej motywowali swój wybór studenci kierunków ścisłych. Większość z nich (3/4 badanych) określiła wybór kształcenia pedagogicznego jako tzw. "dodatkową opcję", „plan awaryjny" w razie niepowodzenia na rynku pracy. Około $1 / 4$ badanych ma za sobą doświadczenia udzielania korepetycji, na bazie których definiują swoje wyobrażenie zawodu nauczyciela.

Z kolei słuchacze studiów podyplomowych, wszyscy deklarowali chęć i konieczność zdobycia dodatkowych kwalifikacji wynikających z obecności uczniów niepełnosprawnych w szkole. Część nauczycieli wprost informowała, że podejmowała studia na prośbę albo pod wpływem sugestii przełożonych, mając świadomość, że jest to argument w utrzymaniu pracy, zdobyciu jej albo możliwości powrotu, jak to jest w przykładowej wypowiedzi:

ponieważ chcę wrócić do pracy z dziećmi w szkole, a nauczyciel wspomagający ma obecnie chyba największe szanse na start od nowa.

Ciekawą grupę stanowiły słuchaczki studiów podyplomowych z zakresu autyzmu. Wśród nich znalazło się kilka kobiet, które podjęły studia również z pobudek osobistych, są bowiem matkami dzieci autystycznych.

Jeden z aspektów badań dotyczył samej potrzeby kształcenia w zakresie pedagogiki specjalnej. Dla studentów, treści dotyczące uczniów ze specjalnymi potrzebami edukacyjnymi, zwłaszcza uczniów niepełnosprawnych nie były zaskoczeniem. Często uzasadniali potrzebę zdobywania tej wiedzy względami praktycznymi - od chęci pomocy osobom niepełnosprawnym po nabywanie umiejętności niezbędnych w warsztacie nauczyciela, również tym dydaktycznym:

wielu ludzi nawet nie zdawało sobie sprawy z problemu, jakim jest zróżnicowanie poziomu ucznia (poziomu jego inteligencji, procesów poznawczych). Jest to o tyle ważne, że od nauczyciela prowadzacego zależy, w jakim stopniu zainteresuje ucznia przedmiotem....

Nie posiadając jeszcze doświadczeń praktycznych, których będą nabierać $\mathrm{w}$ trakcie praktyk studenckich, uznawali niektóre treści za niepotrzebne, argumentując to kształceniem kierunkowym. Natomiast nauczyciele wskazywali na potrzebę nabywania tylko tych treści, które mogą przełożyć na praktykę szkolną. Szczególnie doceniali informacje potrzebne przy rozpoznawaniu zaburzeń, zastosowaniu odpowiednich metod pracy z uczniem ze specjalnymi potrzebami edukacyjnymi oraz pomocne $\mathrm{w}$ konstruowaniu indywidualnych planów edukacyjno-terapeutycznych.

Około $28 \%$ badanych studentów przyznało, że miewa trudności w uczeniu się zagadnień dotyczących niepełnosprawności. Największa z nich związana jest z niemożliwością wyobrażenia sobie, jak odbierają świat osoby niepełnosprawne. Trudność sprawia też interpretacja zachowań i emocji osób niepełnosprawnych albo podobieństwo objawów różnych zaburzeń. Wielu deklarowało chęć, a nawet 
potrzebę, zrównoważenia wiedzy teoretycznej praktyką, np. przez wizytę w szkole, w której mogliby obserwować lekcje prowadzone przez doświadczonych nauczycieli, a zwłaszcza to jak sobie radzą w klasie z niepełnosprawnymi uczniami. Jako pomocne w uczeniu się wymieniali własną tolerancję, zainteresowanie tematem i osobistą znajomość z osobą niepełnosprawną.

Tymczasem nauczyciele trudności upatrywali przede wszystkim $\mathrm{w}$ stosowanym przez wykładowców języku, który określili jako „naukowy”. Problem stanowiły treści niedające się wprost przełożyć na działania praktyczne, co określali jako „wiedzę encyklopedyczną”. Wielu z nich ma ogromne trudności z pisaniem prac dyplomowych w oparciu o badania empiryczne. Podobnie jak u studentów, brak kontaktu z niepełnosprawnymi utrudniał zdobywanie wiedzy i odwrotnie, doświadczenie takiego kontaktu pomagało w jej zdobywaniu. Niektórzy nauczyciele uogólniali też pytanie o trudności, pisząc, że praca z osobami niepełnosprawnymi, ze swej natury, jest ciężka.

Ciekawie rozłożyły się u badanych studentów wyniki wskazań w pytaniach o kontakt z osobami z niepełnosprawnością. W grupie studentów kierunków ścisłych ok $2 / 3$ badanych nie miała takich doświadczeń, w przeciwieństwie do studentów kierunków humanistycznych, wśród których ok 2/3 takie doświadczenia posiadała. Najczęściej były to kontakty w rodzinie albo w szkole: w klasie integracyjnej i w ramach edukacji włączającej. Natomiast, co było do przewidzenia, nauczyciele deklarowali doświadczenia kontaktu z osobami niepełnosprawnymi jednakże o bardzo różnej intensywności. Czasami sama obecność ucznia z niepełnosprawnością w szkole, bez doświadczenia pracy dydaktycznej ani terapeutycznej, traktowana była już jako doświadczenie kontaktu.

Ostatnia część badań dotyczyła wyboru formy kształcenia specjalnego, która zdaniem badanych jest najlepsza dla uczniów z niepełnosprawnością. Studenci wskazywali przede wszystkim na kształcenie integracyjne $40 \%$ oraz kształcenie w szkołach specjalnych $(40 \%$ w grupie studentów kierunków humanistycznych, $32 \%$ kierunków ścisłych). Edukację włączającą wybrało 20\% studentów kierunków humanistycznych i 18\% kierunków ścisłych. Wśród nauczycieli deklaracje okazały się bardziej radykalne: wśród nauczycieli przygotowujących się do pracy z uczniami ze spektrum autyzmu, nikt nie zaznaczył edukacji włączającej jako możliwej formy kształcenia tych uczniów. Odpowiedzi podzieliły badanych na zwolenników szkół specjalnych $44 \%$ i szkół integracyjnych 56\%. Natomiast wśród nauczycieli przygotowujących się do pracy z uczniami z niepełnosprawnością intelektualną przeważyli zwolennicy szkół integracyjnych 35\% i ogólnodostępnych 35\%, zaś 30\% z nich wskazało na szkoły specjalne. Jako argumenty za edukacją włączającą i integracyjną najczęściej podawano większe możliwości socjalizacji uczniów niepełnosprawnych i kontaktu z rówieśnikami. Za systemem segregacyjnym i szkołami specjalnymi przemawiało doświadczenie specjalistów zatrudnionych w tych placówkach i właśnie ich specjalistyczny charakter. 


\section{Podsumowanie}

Wyniki badań ukazały przynajmniej fragment obrazu przygotowania nauczycieli do kształcenia uczniów z niepełnosprawnością $\mathrm{w}$ ramach edukacji włączającej. Sugerują one, że nastawienie wobec określonych form kształcenia tych uczniów może mieć związek nie tylko z samym przygotowaniem czy przeszkoleniem nauczycieli, ale i z ich motywacją. Nauczyciele mają świadomość konieczności całożyciowej edukacji, ale chyba nie do końca są przekonani co do możliwości stosowania różnych form kształcenia uczniów z niepełnosprawnością. Dalszych badań wymagałoby sprawdzenie ich wiedzy na temat samej koncepcji i idei edukacji włączającej, która u wielu budzi skrajne, a czasem negatywne, uczucia. Inaczej rzecz się ma u studentów, zwłaszcza tych, którzy doświadczyli dobrze zorganizowanego kształcenia integracyjnego jeszcze jako uczniowie. Jest $\mathrm{w}$ nich więcej odwagi do podejmowania wyzwań związanych z pracą w innej formie kształcenia niesegregacyjnego. Może to wnikać również z niewielkich albo braku doświadczeń pracy w szkole. Niemniej jednak uzyskane wyniki okazują się podobne do wyników innych badań prowadzonych na innych grupach nauczycieli podobnymi metodami [por. Bąbka, Podgruszewska 2016].

„Nauczyciele szkół ogólnodostępnych (zwłaszcza tzw. EN przedmiotowcy) często nie czują się przygotowani do pracy z uczniami z różnego rodzaju niepełnosprawnościami. Nauczyciele zgłaszają brak wiedzy praktycznej, jak wdrażać ideę edukacji włączającej do codziennej praktyki szkolnej (...)" - czytamy w publikacji ORE [Dziecko..., s. 12]. Wiele badań wskazuje jednak, że problem efektywnej edukacji włączającej nie zostanie rozwiązany za pomocą studiów, kursów czy szkoleń. Wiedza praktyczna powinna iść w parze z wiedzą naukową oraz osobistymi przekonaniami. Na nieskuteczność wielu dotychczasowych działań wskazywała m.in. Zdzisława Janiszewska-Nieścioruk [2016], postulując „wysoko profesjonalne przygotowanie nauczycieli (z uwzględnieniem predyspozycji zawodowych)" [s. 57]. W tę propozycję wpisuje się również głos Iwony Chrzanowskiej i Beaty Jachimczak [2015], sugerujący konieczność kształtowania u nauczycieli takich kompetencji, jak: umiejętność pracy zespołowej, wiary w sukces, otwartości, właściwej motywacji i autorytetu, jako koniecznych w powodzeniu w pracy z uczniami ze specjalnymi potrzebami edukacyjnymi. Studenci z większą otwartością przyjmują kształcenie w zakresie pedagogiki specjalnej. Wydaje się, że młode pokolenie bardziej odważnie traktuje wyzwania związane z kształceniem osób niepełnosprawnych, zaś doświadczonych nauczycieli krępuje, być może, obawa o miejsca pracy. 


\section{Bibliografia}

Bąbka J., Podgruszewska M. (2016), Polityka oświatowa wobec uczniów ze specjalnymi potrzebami edukacyjnymi w perspektywie lokalnej - na podstawie opinii nauczycieli małego miasta, „Niepełnosprawność. Dyskursy Pedagogiki Specjalnej”, nr 22, s. 92-106.

Chrzanowska I. (2015), Pedagogika specjalna. Od tradycji do wspótczesności, Oficyna Wydawnicza „Impuls”, Kraków.

Cylkowska-Nowak M. (2000), Społeczne funkcje szkolnictwa w Japonii i Stanach Zjednoczonych. Studium z pedagogiki porównawczej, Wydawnictwo Edytor, Poznań-Toruń.

Dryżałowska G. (2004), Integracja edukacyjna a integracja społeczna, [w:] Integracja społeczna osób niepełnosprawnych, G. Dryżałowska, H. Żuraw (red.), Wydawnictwo Żak, Warszawa.

Dudzińska A., Roszewska K. (2016), Praktyczna realizacja polityki oświatowej wobec uczniów z niepetnosprawnościami, „Niepełnosprawność. Dyskursy Pedagogiki Specjalnej”, nr 22, s. 185-201.

Dziecko z niepetnosprawnościq w przedszkolu i szkole ogólnodostępnej - wyzwanie dla JST, (2015), ORE, Warszawa.

Gajdzica Z. (2011), Sytuacja trudne w opinii nauczycieli klas integracyjnych, Oficyna Wydawnicza „Impuls”, Kraków.

Gajdzica Z., Iwińska J. (2013), Reorganizacja sieci szkót specjalnych - oszczędność, racjonalizacja przestrzeni, profesjonalizacja usług czy zwykła głupota [w:] Człowiek z niepetnosprawnościa w rezerwacie przestrzeni publicznej, Oficyna Wydawnicza „Impuls”, Kraków.

Hizn A. (1999), Perspectiven: Von der Integration zur Inclusive Education? [w:] Entwicklung Standorte - Perspectiven, P. Achtel, D. Schmetz (red.), Sonderpädagogische Kongress, Würzburg.

Jachimczak B, Chrzanowska I. (2015), Kompetencje wspótczesnych nauczycieli a praca z dzieckiem ze specjalnymi potrzebami edukacyjnymi w szkole [w:] Nauczyciel w nowoczesnym świecie od założeń teoretycznych do rozwoju kompetencji, J. Pyżalski (red.), theQ studio, Łódź.

Janiszewska-Nieścioruk Z. (2016), (Nie)dojrzałość pro inkluzyjnych zmian w kształceniu osób z niepetnosprawnościa, "Niepełnosprawność. Dyskursy Pedagogiki Specjalnej”, nr 22, s. 47-59.

Kupisiewicz M. (2014), Stownik pedagogiki specjalnej, APS, Wydawnictwo Naukowe PWN, Warszawa.

Sadowska S. (2016), Polityka oświatowa w rozwiązywaniu kwestii ksztatcenia uczniów z niepetnosprawnościami (1989-2016), „Niepełnosprawność. Dyskursy Pedagogiki Specjalnej”, nr 22, s. 13-36.

Szumski G. (2009), Integracyjne kształcenie niepetnosprawnych, Wydawnictwo APS, Warszawa.

Szumski G. (2010), Wokót edukacji włączającej. Efekty kształcenia uczniów z niepetnosprawnościa intelektualna w stopniu lekkim w klasach specjalnych, integracyjnych i ogólnodostępnych, Wydawnictwo APS, Warszawa.

Zamkowska A. (2011), Szkolnictwo specjalne w roli tradycyjnej i nowej [w:] Osoba z upośledzeniem umysłowym w realiach wspótczesnego świata, M. Chodkowsk, D. Osik-Chudowolska, Oficyna Wydawnicza „Impuls”, Kraków. 


\section{Akty prawne}

Deklaracja z Salamanki oraz wytyczne dla działań w zakresie specjalnych potrzeb edukacyjnych przyjęte przez Światową Konferencję dotyczącą Specjalnych Potrzeb Edukacyjnych: Dostęp i jakość, Salamanka, Hiszpania 7-10 czerwca 1994 r., UNESCO 1994, http://www.eurosprawni.org/pl/prawo/314-deklaracja-z-salamanki-oraz-wytyczne-dla -dzialan-w-zakresie-specjalnych-potrzeb-edukacyjnych [dostęp: 18.05.2017].

Rozporządzenie Ministra Edukacji Narodowej z dnia 12 marca 2009 r. w sprawie szczegółowych kwalifikacji wymaganych od nauczycieli oraz określenia szkół i wypadków, w których można zatrudnić nauczycieli niemających wyższego wykształcenia lub ukończonego zakładu kształcenia nauczycieli (załącznik do Obwieszczenia Ministra Edukacji Narodowej z dnia 6 sierpnia 2015 r., Dz. U. poz. 1264).

Rozporządzenie Ministra Edukacji Narodowej z dnia 24 lipca 2015 r. w sprawie warunków organizowania kształcenia, wychowania i opieki dla dzieci i młodzieży niepełnosprawnych, niedostosowanych społecznie i zagrożonych niedostosowaniem społecznym (Dz. U. z 2015 r., poz. 1113).

Rozporządzenie Ministra Edukacji Narodowej z dnia 30 kwietnia 2013 r. w sprawie zasad udzielania i organizacji pomocy psychologiczno-pedagogicznej w publicznych przedszkolach, szkołach i placówkach (Dz. U. z 2013 r., poz. 532).

Rozporządzenie Ministra Nauki i Szkolnictwa Wyższego z dnia 17 stycznia 2012 roku w sprawie standardów kształcenia przygotowującego do wykonywania zawodu nauczyciela, Dz. U. z 2012 r., poz. 131. 